\title{
PENGARUH ANALISIS JABATAN DAN PERENCANAAN SUMBER DAYA MANUSIA TERHADAP REKRUTMEN KARYAWAN
}

\author{
Laksmi Sito Dwi Irvianti $^{1}$; Julius Adi ${ }^{2}$ \\ 1,2 Jurusan Manajemen, Fakultas Ekonomi dan Bisnis, Universitas Bina Nusantara, \\ Jln. K.H. Syahdan No. 9, Palmerah, Jakarta Barat 11480 \\ laksmisito@binus.ac.id
}

\begin{abstract}
PD Karunia Jaya is a trading company engaged in supplying spare parts of four-wheeled vehicles. The company originally only deals in one brand, namely Toyota. But, with more and more development, it grew to deal with four brands, including Toyota, Suzuki, Daihatsu, and Isuzu. Due to the increase in the number of brands, the company certainly requires added labor. The purpose of this study is to perform role analysis and human resources planning on employee recruitment at the company. Results obtained can be used as a reference or a guide for companies in developing effective recruitment. The method of analysis used in this study are correlation analysis and linear regression. Data is obtained by spreading the questionnaire to employees. Results achieved in this research is that role analysis is strongly associated with the recruitment at (0.702) and HR planning with recruitment at (0.736). Job analysis and human resource planning is strongly correlated to recruitment at (0.778). Also job analysis has medium influence with recruitment at (0.492) and HR planning with the recruitment at (0.541). Job analysis and human resources planning is associated with the recruitment at (.605). With this results it is expected that role of job analysis and human resource planning can be a major factor to improve the effectiveness of employee recruitment.
\end{abstract}

Keywords: job analysis, human resources planning, employee recruitment

\begin{abstract}
ABSTRAK
PD Karunia Jaya merupakan perusahaan dagang yang bergerak di bidang supplier suku cadang kendaraan roda empat. Perusahaan pada awalnya hanya bermain di satu merek yaitu Toyota. Tetapi, semakin lama semakin berkembang sehingga bertambah menjadi memegang 4 merek kendaraan roda empat, meliputi Toyota, Suzuki, Daihatsu, dan Isuzu. Karena bertambahnya merek, tentunya membutuhkan pertambahan tenaga kerja. Tujuan penelitian ini ialah melakukan peranan analisis jabatan dan perencanaan sumber daya manusia terhadap rekrutmen karyawan di perusahaan. Hasil penelitian yang diperoleh dapat dijadikan sebagai acuan atau pedoman bagi perusahaan dalam membuat suatu perekrutan yang efektif. Metode analisis yang digunakan dalam penelitian ini adalah analisis korelasi dan regresi linear. Data diperoleh dengan menyebar kuesioner terhadap karyawan. Hasil yang dicapai dalam penelitian ini adalah analisis jabatan berhubungan kuat dengan rekrutmen sebesar $(0,702)$ dan perencanaan SDM dengan rekrutmen sebesar $(0,736)$. Analisis jabatan dan perencanaan SDM berhubungan kuat dengan rekrutmen sebesar $(0,778)$. Selain itu, memiliki pengaruh analisis jabatan berpengaruh kuat dengan rekrutmen sebesar $(0,492)$ dan perencanaan SDM dengan rekrutmen sebesar $(0,541)$. Analisis jabatan dan perencanaan SDM berhubungan yang kuat dengan rekrutmen sebesar $(0,605)$. Dengan ini diharapkan peranan analisis jabatan dan perencanaan SDM dapat dijadikan faktor utama untuk meningkatkan efektivitas rekrutmen karyawan.
\end{abstract}

Kata kunci: analisis jabatan, perencanaan sdm, rekrutmen karyawan 


\section{PENDAHULUAN}

Manajemen Sumber Daya Manusia (SDM) merupakan suatu jenis pengakuan atas pentingnya unsur manusia sebagai sumber daya yang cukup potensial, yang perlu dikembangkan sedemikian rupa sehingga mampu memberikan kontribusi maksimal bagi organisasi, dan pengembangan SDM tersebut. Menurut Mondy, W.R. (2010:4), "Human Resource Management is utilization of individuals to achieve organizational objectives." Sedangkan menurut Milner dan Crane (2005:12), "Human resources management is the process developing, applying and evaluated policies, procedures, methods and programs relating to the individual in the organization.” Jadi, dapat dikatakan bahwa manajemen SDM memegang peranan penting dalam suatu organisasi untuk mencapai tujuannya.

Sebagaimana elemen organisasi yang lain, SDM harus dikelola dengan baik. Bahkan bisa dikatakan bahwa pengelolaan organisasi pada dasarnya adalah proses pengelolaan manusia. Semua organisasi apapun jenis, ukuran, fungsi ataupun tujuannya harus beroperasi dengan dan melalui manusia. Dibandingkan dengan elemen-elemen yang lain, memang dapat dikatakan bahwa manusia merupakan elemen yang paling dinamis dan kompleks. Seringkali efisiensi pelaksanaan organisasi tergantung pada pengelolaan dan pendayagunaan manusia, maka setiap manajer harus mampu bekerja secara efektif dengan manusia dan harus mampu memecahkan bermacam-macam persoalan sehubungan dengan pengelolaan SDM. Pengelolaan SDM di dalam organisasi kemudian dikenal dengan manajemen personalia dan berkembang menjadi Manajemen Sumber Daya Manusia.

Manusia akan mampu untuk bekerja dengan dengan baik bila ia ditempatkan pada posisi dengan jabatan yang sesuai dengan minat dan kemampuannya serta bila ia bisa memenuhi kebutuhannya dengan melakukan pekerjaan itu. lni berarti bahwa perusahaan harus bisa menempatkan orang pada jabatan-jabatan yang sesuai dengan minat dan kemampuannya, dengan tidak lupa mempertimbangkan upaya pemenuhan kebutuhannya.

Permasalahan yang terdapat dalam perusahaan adalah kurangnya kinerja karyawan. Hal ini dapat dilihat dari tingkat absensi karyawan yang tinggi, kinerja tidak cukup baik, dan tingkat disiplin karyawan yang rendah. Jadi, dapat dilihat adanya kesalahan dalam dalam proses rekrutmen, di mana proses rekrutmen itu sendiri adalah proses mencari orang yang bekerja. Menurut Ivancevich, J.M (2007:190), "Recruiting requirements is the recruiting process necessarily begins with detailed job specifications." Sedangkan rekrutmen menurut Byars dan Rue (2006:111) adalah "Process of seeking and attracting a pool of people from which qualified candidates for job vacancies can be chosen." Rekrutmen yang dilakukan perusahaan akan menentukan proses seleksi selanjutnya, yang akan menghasilkan karyawan bagi perusahaan. Agar rekrutmen yang dilakukan perusahaan menjadi efektif, maka perlu dilakukan analisis jabatan dan perencanaan SDM.

Mondy, W.R (2010:106) mendefinisikan Human Resource Planning adalah "Human resource planning is the systematic process of matching the internal and external supply of people with job openings anticipated in the organization over a specified period of time." Menurut Millmore Lewis, Saunders, Thornhill dan Morrow (2007:2007), "Human resource planning is about ensuring that the correct number and mix of employees is available at the right place at the right time. The success of HRP is paramount to the survival of the organization and the complexities associated with the planning process are enormous." Dari uraian tersebut, dapat disimpulkan bahwa perencanaan SDM akan menentukan kapan dan bagaimana perusahaan harus melakukan rekrutmen untuk mengisi posisi yang kosong.

Bagaimana suatu rekrutmen dapat efektif ?. Perusahaan perlu melakukan analisis jabatan agar rekrutmen yang dilakukan dapat efektif. Mondy, W.R (2010:92) mendefinisikan bahwa, “Job analysis is the systhematic process of determining the skills, duties and knowledge required for performing jobs 
in an organization. Job analysis information is used to prepare both a job description and job specification. The job specification is a document that outlines the minimum acceptable qualifications a person should process to perform a particular job. The Job description is a document that provides information regarding the essential task, duties, and responsibility of a job.” Dengan adanya job description dan job specification untuk tiap posisi, maka perusahaan dapat merekrut orang yang tepat untuk menduduki posisi tersebut sehingga membantu pencapaian tujuan organisasi.

Dalam penelitian ini, PD Karunia Jaya dipilih sebagai objek penelitian ini. Perusahaan merupakan perusahaan dagang yang bergerak di bidang supplier suku cadang kendaraan roda empat. Rekrutmen merupakan suatu tantangan tersendiri bagi para manajer karena sangat menentukan pencapaian tujuan perusahaan. Selama ini, sumber rekrutmen yang dilakukan perusahaan hanya dari mulut ke mulut, tanpa adanya iklan lowongan kerja resmi dan hal ini menyebabkan pelamar yang masuk menjadi kurang berkualitas. Dalam suatu perusahaan, tenaga kerja merupakan salah satu faktor penting yang menentukan tercapainya tujuan perusahaan.

Identifikasi masalah dalam penelitian ini adalah (1) Bagaimana pengaruh antara analisis jabatan terhadap rekruitmen karyawan?, (2) Bagaimana pengaruh antara perencanaan Sumber Daya Manusia terhadap rekruitmen karyawan?, dan (3) Bagaimana pengaruh simultan antara analisis jabatan dan perencanaan Sumber Daya Manusia terhadap rekrutmen karyawan?. Sedangkan desain penelitiannya adalah sebagai berikut. Penelitian ini merupakan penelitian deskriptif dengan jenis penelitian studi kasus untuk menganalisis bagaimana pengaruh analisis jabatan dan perencanaan sumber daya manusia terhadap efektivitas rekrutmen karyawan di PD. Karunia Jaya. Menurut pendapat Sukardi (2003:157), penelitian deskriptif adalah metode penelitian yang berusaha menggambarkan dan menginterpretasi objek pada adanya. Penelitian ini juga disebut non-eksperimen, karena pada penelitian ini peneliti tidak melakukan kontrol dan memanipulasi variabel penelitian. Dengan metode deskriptif, peneliti memungkinkan untuk melakukan hubungan antar variabel, menguji hipotesis, mengembangkan generalisasi, dan mengembangkan teori yang memiliki validitas universal.

\section{METODE PENELITIAN}

Jenis data penelitiannya adalah jenis data kuantitatif dan kualitatif, sedangkan sumber data adalah data primer (yang diperoleh dari kuesioner dan wawancara), dan data sekunder (data internal perusahaan). Sementara itu, teknik pengumpulan datanya adalah sebagai berikut. Teknik dibahas di atas bahwa penulis menggunakan data primer dan metode yang ada beberapa cara, yaitu (1) Metode observasi, merupakan pengumpulan data primer dalam pencatatan pola perilaku subjek (orang), atau objek (benda) atau kejadian yang sistematik tanpa adanya pertanyaan atau komunikasi dengan individu-individu yang diteliti; dan (2) Metode survei.

Ada 2 teknik pengumpulan metode survei, yaitu wawancara dan kuesioner. Wawancara adalah teknik poengumpulan data dalam metode survei yang menggunakan pertanyaan secara lisan kepada subjek penelitian. Teknik wawancara dilakukan jika peneliti memerlukan komunikasi atau hubungan dengan responden. Data yang dikumpulkan umumnya berupa masalah tertentu yang bersifat kompleks, sensitif atau kontrovesional sehingga kemungkinan jika dilakukan dengan teknik kuesioner akan kurang mendapat tanggapan responden. Teknik wawancara dilakukan terutama untuk responden yang tidak dapat membaca-menulis atau jenis pertanyaan yang memerlukan penjelasan dari pewawancara sebagai data penelitian. Wawancara dapat dilakukan dengan tatap muka dan melalui telepon. Sedangkan kuesioner adalah teknik pengumpulan data primer, di mana pengumpulan data penelitian pada kondisi tertentu kemungkinan tidak memerlukan kehadiran peneliti. Pertanyaan 
peneliti dan jawaban responden dapat dikemukakan secara tertulis melalui suatu kuesioner. Teknik ini memberikan tanggung jawab kepada responden untuk membaca dan menjawab pertanyaan.

Kuesioner dalam penelitian ini dibuat dengan skala Likert. Menurut Sugiyono (2008:132), dalam skala Likert kemungkinan jawaban bukan hanya jawaban setuju atau tidak setuju, tetapi dibuat dengan lebih banyak kemungkinan jawaban. Instrumen penelitian ini menggunakan skala Likert yang berbentuk pilihan ganda (check list). Penulis mengumpulkan sejumlah pernyataan yang berkaitan masalah yang akan diteliti, kemudian responden memilih salah satu jawaban dari sejumlah kategori jawaban yang tersedia, atau menjawab langsung pertanyaan tanpa harus memilih kategori jawaban yang tersedia.

\section{Metode Analisis}

Data yang diperoleh dari akan diuji dan dianalisis dengan metode sebagai berikut. Pertama, uji validitas, dilakukan untuk menunjukkan sejauh mana suatu alat ukur cocok untuk mengukur sesuatu yang ingin diukur. Jadi, dapat dikatakan bahwa semakin tinggi validitas suatu alat ukur, maka alat ukur tersebut semakin mengenai sasarannya, atau semakin menunjukkan sesuatu yang seharusnya diukur. Metode untuk uji validitas yang penulis gunakan dalam penelitian ini adalah One Short Method, yaitu dengan melihat berdasarkan koefisien korelasi pada tabel $r$ dari setiap pertanyaan yang ada. Apabila korelasi > r tabel, maka pertanyaan tersebut dinyatakan valid.

Kedua, uji reliabilitas. Reliabilitas adalah indeks yang menunjukkan sejauh mana suatu alat ukur dapat dipercaya atau dapat diandalkan. Suatu alat ukur dikatakan mempunyai keandalan konsistensi internal apabila item penyusunannya konsisten mengukur hanya variabel yang dikehendaki dan ini menunjukkan item-item tersebut mempunyai rata-rata korelasi antar item yang tinggi. Dengan kata lain, reliabilitas menunjukkan konsistensi suatu alat ukur yang umumnya digunakan ialah dengan mencari koefisien kehandalan alat ukur yang menentukan mutu keseluruhan proses pengumpulan data, yaitu dengan menggunakan rumus koefisien Alpha $(\alpha)$ metode Cronbach (Sugiyono, 2008:20). Besarnya Alpha Cronbach ini berkisar antara 0-1. Semakin besar nilai koefisien keandalannya, maka semakin tinggi keandalan alat ukurnya. Besarnya alpha berkorelasi positif dengan jumlah variabel yang digunakan, jadi semakin rendah nilai rata-rata korelasi antar variabel, maka akan semakin rendah pula nilai alpha. Dengan batas minimum alpha $=0.6$.

Ketiga, uji normalitas. Pengujian normalitas data dilakukan dengan uji Kolmogorov-Smirnov dengan tingkat signifikansi 0,05. Dalam uji normalitas data (Goodness of Fit), pengujian dilakukan untuk mengetahui apakah distribusi frekuensi hasil pengamatan (observed frequencies distribution) sesuai dengan expected normal frequencies distribution. Hipotesis hasil yang akan diuji mengatakan bahwa distribusi frekuensi pengamatan adalah sesuai dengan distribusi frekuensi yang diharapkan/teoritis. Dalam uji Kolmogorov-Smirnov, yang diperbandingkan adalah distribusi frekuensi kumulatif hasil pengamatan dengan distribusi frekuensi kumulatif yang diharapkan (actual observed cumulative frequency dengan expected cumulative frequency).

Keempat, regresi. Untuk mengetahui seberapa besar pengaruh analisis jabatan dan perencanaan sumber daya manusia terhadap efektivitas rekrutmen karyawan, maka peneliti menggunakan analisis regresi dengan rumus sebagai berikut: $\mathrm{Y}=\mathrm{a}+\mathrm{bx}$. Kelima, korelasi. Untuk menganalisis seberapa erat hubungan analisis jabatan dan perencanaan sumber daya manusia terhadap efektivitas rekrutmen karyawan, maka peneliti akan menggunakan metode analisis korelasi linear sebagai berikut: 
Koefisien Determinasi:

$$
r^{2}=\frac{\sum x 1 y+b 2 \sum x 2 y}{\sum y^{2}}
$$

Keenam, uji hipotesa. Hipotesis menurut J. Supranto (2001) adalah suatu anggapan dugaan yang belum tentu kebenarannya. Perumusan hipotesis akan diuji diberi simbol H0, sedangkan hipotesis alternatif diberi simbol H1. Untuk mengetahui apakah anggapan itu benar, maka perlu suatu tes yang dinamakan uji T hipotesis, yang merupakan prosedur yang memungkinkan untuk mengambil keputusan dengan tingkat (1-a) sebesar 95\% atau tingkat kesalahan $(\alpha)$ sebesar 5\%, dan derajat kebebasan (n-2).

\section{HASIL DAN PEMBAHASAN}

\section{Uji Validitas Data}

Uji validitas untuk tiap instrumen dilakukan dengan menggunakan rumus korelasi Pearson Product Moment dengan mengorealisasikan skor tiap butir pernyataan (sebagai variabel X) dengan skor total (variabel Y). Melakukan uji coba pengukur tersebut pada sejumlah responden, sangat disarankan agar jumlah responden untuk uji coba minimal 30 responden. Dengan jumlah minimal 30 orang ini, distributor nilai (skor) akan lebih mendekati kurva normal (Umar, 2008:52), dengan tingkat interval kepercayaan 95\%. Dasar pengambilan keputusan pada uji validitas adalah sebagai berikut. Jika $\mathrm{r}$ hitung $>\mathrm{r}$ tabel, maka butir atau pernyataan tersebut valid, dan jika $\mathrm{r}$ hitung $<\mathrm{r}$ tabel, maka butir atau pernyataan tersebut tidak valid.

Nilai r hitung didapat dari hasil perhitungan korelasi Pearson Product Moment antara skor tiap butir pernyataan dengan skor total dan nilai $r$ tabel adalah 0,31 . Semua pernyataan pada variabel analisis jabatan dinyatakan valid karena $\mathrm{r}$ hitung masing-masing $>\mathrm{r}$ tabel yaitu 0,31; semua pernyataan pada variabel perencanaan SDM dinyatakan valid karena $r$ hitung masing-masing $>r$ tabel yaitu 0,31; dan semua pernyataan pada variabel efektivitas rekrutmen karyawan dinyatakan valid karena $\mathrm{r}$ hitung masing-masing $>\mathrm{r}$ tabel yaitu 0,31 .

\section{Uji Reliabilitas Data}

Dalam melakukan pengujian reliabilitas populasi dan sampel yang digunakan juga sebanyak 30 responden. Dasar pengambilan keputusan pada uji reliabilitas adalah (1) Bila Cronbach Alpha > 0,6 maka kuesioner yang diuji reliabel, dan (2) Bila Cronbach Alpha $<0,6$ maka kuesioner yang diuji tidak reliabel. Dari uji reliabilitas, diperoleh bahwa nilai Cronbach Alpha untuk analisis jabatan, perencanaan SDM, dan efektivitas rekrutmen masing-masing adalah 0.902, 0.734, dan 0.826 sehingga dapat dikatakan reliabel.

\section{Uji Normalitas Data}

Uji normalitas untuk tiap variabel dilakukan dengan menggunakan alat uji KORMOGOROV SMIRNOV. Dasar pengambilan keputusan pada uji normalitas data ini adalah sebagai berikut (1) Jika signifikansi (Sig) atau nilai probabilitas $>0,05$, maka data berdistribusi normal, dan (2) jika signifikansi (Sig) atau nilai probabilitas $<0,05$, maka data tidak berdistribusi normal. Angka signifikansi (Sig) dapat diperoleh melalui perhitungan test of normality atau plot melalui alat bantu SPSS 16, dan angka 0,05 merupakan tingkat kesalahan atau $\alpha$. 
Tabel 1 Kolmogorov- Smirnov Test Variabel Analisis Jabatan

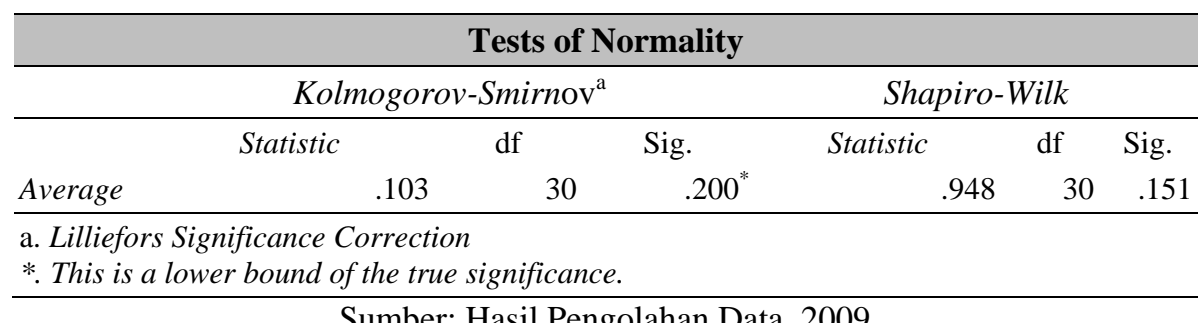

Sumber: Hasil Pengolahan Data, 2009

Jika dilihat dari tabel di atas, variabel analisis jabatan memiliki Sig $=0,2>0,05$, maka data analisis jabatan berdistribusi normal.

Tabel 2 Kolmogorov- Smirnov Test Variabel Perencanaan SDM

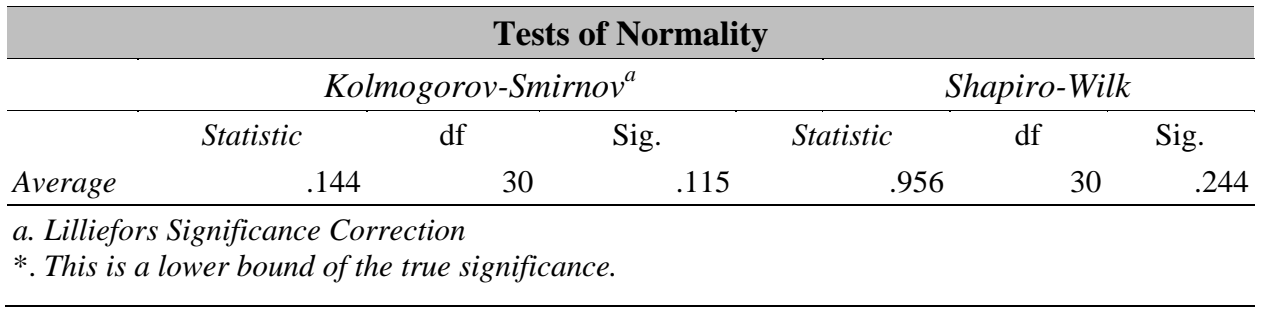

Sumber: Hasil Pengolahan Data, 2009

Jika dilihat dari tabel di atas, variabel perencanaan SDM memiliki Sig $=0,115>0,05$, maka data analisis jabatan berdistribusi normal.

Tabel 3 Kolmogorov- Smirnov Test Variabel Efektivitas Rekrutmen Karyawan

\begin{tabular}{lcccccrr}
\hline \multicolumn{7}{c}{ Tests of Normality } \\
\hline \multicolumn{7}{c}{ Kolmogorov-Smirnov $^{a}$} & \multicolumn{3}{c}{ Shapiro-Wilk } \\
\hline Statistic & $\mathrm{df}$ & \multicolumn{1}{c}{ Sig. } & Statistic & $\mathrm{df}$ & \multicolumn{1}{c}{ Sig. } \\
\hline Average & .132 & 30 & .192 & .943 & 30 & .108
\end{tabular}

a. Lilliefors Significance Correction

Sumber: Hasil Pengolahan Data, 2009

Jika dilihat dari tabel di atas, variabel efektivitas rekrutmen karyawan memiliki Sig $=0,192>0,05$, maka data analisis jabatan berdistribusi normal.

\section{Hubungan antara Analisis Jabatan terhadap Rekrutmen Karyawan}

Besarnya hubungan analisis jabatan (X1) terhadap rekrutmen karyawan (Y) yang dihitung dengan koefisien korelasi adalah 0,702. Hal ini menunjukkan bahwa adanya hubungan yang kuat antara analisis jabatan dengan rekrutmen karyawan. Kontribusi analisis jabatan terhadap rekrutmen karyawan adalah sebesar KP $=\mathrm{r}^{2} \times 100 \%=0,702^{2} \times 100 \%=49.28 \%$. Variabel efektifitas rekrutmen karyawan dijelaskan oleh variabel analisis jabatan sebesar 49,28\% dan sisanya 50,72\% ditentukan oleh variabel lain, yang tidak dapat dijelaskan dalam penelitian ini. 
Untuk mengetahui generalisasi dari hubungan variabel analisis jabatan dengan variabel efektifitas rekrutmen karyawan, maka dilakukan uji signifikansi sebagai berikut.

Hipotesis:

Ho = Variabel analisis jabatan tidak berhubungan secara signifikan dengan variabel rekrutmen karyawan

$\mathrm{H1}$ = Variabel analisis jabatan berhubungan secara signifikan dengan variabel rekrutmen karyawan

Dasar pengambilan keputusan, yaitu (1) Jika nilai probabilitas lebih kecil atau sama dengan nilai probabilitas Sig atau (Sig < 0,05), maka Ho ditolak dan H1 diterima, artinya signifikan; (2) Jika nilai probabilitas lebih besar atau sama dengan nilai probabilitas Sig atau (Sig $>0,05)$, maka Ho diterima dan H1 ditolak, artinya tidak signifikan.

Dari hasil uji signifikansi koefisien korelasi untuk dua sisi (2-tailed) dari output menghasilkan angka sebesar 0,000. Jika dibandingkan dengan $\alpha=0,05$, maka nilai Sig lebih kecil dari $\alpha$ (Sig < $\alpha$ ), yaitu $0,000<0,05$, yang artinya Ho ditolak atau H1 diterima. Kesimpulannya adalah variabel analisis jabatan berhubungan secara signifikan dengan rekrutmen karyawan. Angka 0,05 digunakan karena hasil penelitian SPSS 16 memberikan angka signifikan sebesar angka 0,05 yang ditandai dengan $(* *)$. Standard SPSS berada di antara 0,01 sampai 0,05.

\section{Hubungan antara Perencanaan SDM terhadap Rekrutmen Karyawan}

Besarnya hubungan perencanaan SDM (X2) terhadap rekrutmen karyawan (Y) yang dihitung dengan koefisien korelasi adalah 0,736. Hal ini menunjukkan ada hubungan yang kuat antara perencanaan SDM dengan rekrutmen karyawan. Sumbangan analisis jabatan dengan rekrutmen karyawan adalah sebesar $\mathrm{KP}=\mathrm{r}^{2} \mathrm{x} 100 \%=0,736^{2} \times 100 \%=54,16 \%$ variabel rekrutmen karyawan dijelaskan oleh variabel perencanaan SDM dan sisanya 45,84\% ditentukan oleh variabel lain, yang tidak dapat dijelaskan dalam penelitian ini.

Untuk mengetahui generalisasi dari hubungan variabel perencanaan SDM dengan variabel rekrutmen karyawan, maka dilakukan uji signifikansi sebagai berikut.

Hipotesis:

Ho = Variabel perencanaan SDM tidak berhubungan secara signifikan dengan variabel rekrutmen karyawan

$\mathrm{H} 1$ = Variabel perencanaan SDM berhubungan secara signifikan dengan variabel rekrutmen karyawan

Dasar pengambilan keputusan, yaitu (1) Jika nilai probabilitas lebih kecil atau sama dengan nilai probabilitas Sig atau (Sig < 0,05), maka Ho ditolak dan H1 diterima, artinya signifikan; (2) Jika nilai probabilitas lebih besar atau sama dengan nilai probabilitas Sig atau (Sig > 0,05), maka Ho diterima dan $\mathrm{H} 1$ ditolak, artinya tidak signifikan.

Dari hasil uji signifikansi koefisien korelasi untuk dua sisi (2-tailed) dari output menghasilkan angka sebesar 0,000. Jika di bandingkan dengan $\alpha=0,05$, maka nilai Sig lebih kecil dari $\alpha$ (Sig < $\alpha$ ), yaitu 0,000 < 0,05 yang artinya Ho ditolak atau H1 diterima. Kesimpulannya adalah variabel analisis jabatan berhubungan secara signifikan dengan rekrutmen karyawan.

\section{Hubungan antara Analisis Jabatan dan Perencanaan Sumber Daya Manusia terhadap Rekrutmen Karyawan}

Besarnya hubungan analisis jabatan (X1) dan perencanaan SDM (X2) terhadap rekrutmen karyawan (Y) yang dihitung dengan koefisien korelasi adalah 0,778 atau (Ryx1x2 =0,778). Hal ini 
menunjukkan hubungan yang kuat antara analisis jabatan dan perencanaan SDM dengan rekrutmen karyawan. Koefisien korelasi bertanda (+), artinya hubungan antara analisis jabatan dan perencanaan SDM dengan rekrutmen karyawan searah sehingga jika analisis jabatan dan perencanaan SDM naik, maka efektivitas rekrutmen karyawan juga akan naik. Dapat diartikan bahwa apabila analisis jabatan dan perencanaan SDM di perusahaan telah berperan dengan baik, maka diharapkan dapat meningkatkan rekrutmen karyawan yang lebih baik lagi.

Kontribusi analisis jabatan dan perencanaan SDM dengan rekrutmen terdapat pada R square adalah sebesar 0,605 (adalah pengkuadratan dari koefisien korelasi 0,778 atau $0,778^{2}$ ). $\mathrm{R}$ square dapat disebut koefisien determinasi yang dalam hal ini berarti 60,5 \%. Artinya adalah sumbangan $60,5 \%$ variabel rekrutmen karyawan ini dijelaskan oleh variabel analisis jabatan dan perencanaan SDM dan sisanya 39,5\% ditentukan oleh variabel lain yang tidak dapat dijelaskan dalam penelitian ini.

Hipotesis:

Ho = Variabel analisis jabatan dan perencanaan SDM tidak berhubungan secara signifikan dengan variabel rekrutmen karyawan

$\mathrm{H} 1$ = Variabel analisis jabatan dan perencanaan SDM berhubungan secara signifikan dengan variabel rekrutmen karyawan

Dasar pengambilan keputusan, yaitu (1) Jika nilai probabilitas lebih kecil atau sama dengan nilai probabilitas Sig atau (Sig< 0,05), maka Ho ditolak dan H1 diterima, artinya signifikan; (2) Jika nilai probabilitas lebih besar atau sama dengan nilai probabilitas Sig atau (Sig > 0,05), maka Ho diterima dan H1 ditolak, artinya tidak signifikan.

Berdasarkan hasil uji dua sisi (2-tailed) (diukur dari probabilitas atau Sig. F change) menghasilkan angka sebesar 0,000. Jika dibandingkan dengan $\alpha=0,05$, maka nilai Sig lebih kecil dari $\alpha$ (Sig $<\alpha$ ), yaitu 0,000 $<0,05$, yang artinya Ho ditolak atau H1 diterima. Kesimpulannya adalah variabel analisis jabatan dan perencanaan SDM berhubungan secara signifikan dengan variabel rekrutmen karyawan.

\section{Pengaruh Analisis Jabatan terhadap Rekrutmen Karyawan}

Besarnya pengaruh analisis jabatan (X1) terhadap rekrutmen karyawan (Y) yang dihitung dengan regresi linear adalah $R$. square sebesar 0,702 . Hal ini menunjukkan ada pengaruh yang kuat dan searah antara analisis jabatan dengan rekrutmen karyawan. $\mathrm{R}$ square dapat disebut koefisien determinasi, yang dalam hal ini berarti 49,3\%. Artinya, sumbangan 49,3\% variabel rekrutmen karyawan ini dijelaskan oleh variabel analisis jabatan dan sisanya 50,7\% ditentukan oleh variabel lain yang tidak dapat dijelaskan dalam penelitian ini.

Persamaan regresi yang didapat antara analisis jabatan (X1) terhadap rekrutmen karyawan (Y) adalah $\mathrm{Y}=0.813+0.754 \mathrm{X} 1$. Dari persamaan tersebut, dapat diartikan bahwa dengan penerapan analisis jabatan (X1) makin baik maka rekrutmen karyawan (Y) menjadi lebih baik pula. Jika perusahaan tidak menerapkan analisis jabatan (X1), maka rekrutmen (Y) adalah sebesar 0.813 .

\section{Pengaruh Perencanaan Sumber Daya Manusia terhadap Rekrutmen Karyawan}

Besarnya pengaruh perencanaan SDM (X1) terhadap rekrutmen karyawan (Y) yang dihitung dengan regresi linear adalah $R$. square sebesar 0,541 . Hal ini menunjukkan ada pengaruh yang kuat dan searah antara perencanaan SDM dengan rekrutmen karyawan. $R$ square dapat disebut koefisien determinasi, yang dalam hal ini berarti 54,1\%. Artinya, sumbangan 54,1\% variabel rekrutmen karyawan ini dijelaskan oleh variabel perencanaan SDM dan sisanya 45,9\% ditentukan oleh variabel 
lain yang tidak dapat dijelaskan dalam penelitian ini. Persamaan regresi yang didapat antara perencanaan SDM (X2) terhadap rekrutmen karyawan $(\mathrm{Y})$ adalah $\mathrm{Y}=0.413+0.881$ X2. Dari persamaan tersebut, dapat diartikan bahwa dengan penerapan perencanaan SDM (X2) makin baik, maka rekrutmen karyawan (Y) menjadi lebih efektif pula.

\section{Pengaruh Analisis Jabatan dan Perencanaan Sumber Daya Manusia terhadap Rekrutmen Karyawan}

Besarnya pengaruh analisis jabatan (X1) dan perencanaan SDM (X2) terhadap rekrutmen karyawan (Y), yang dihitung dengan regresi linear adalah $R$. square sebesar 0,605. Hal ini menunjukkan ada pengaruh yang kuat dan searah antara analisis jabatan dan perencanaan SDM dengan rekrutmen karyawan. $R$ square dapat disebut koefisien determinasi yang dalam hal ini berarti $60,5 \%$. Artinya, sumbangan 60,5\% variabel rekrutmen karyawan ini dijelaskan oleh variabel analisis jabatan dan perencanaan SDM, sisanya 39,5\% ditentukan oleh variabel lain yang tidak dapat dijelaskan dalam penelitian ini. Persamaan regresi yang didapat antara perencanaan SDM (X) terhadap rekrutmen karyawan $(\mathrm{Y})$ adalah $\mathrm{Y}=0.154+0.572 \mathrm{X} 1+0.388 \mathrm{X} 2$. Jika penerapan analisis jabatan (X1) dan perencanaan SDM (X2) makin baik, maka rekrutmen karyawan (Y) akan makin efektif pula.

\section{Pembahasan Analisis Jabatan}

Proses analisis jabatan yang telah diterapkan dalam perusahaan dimulai dengan proses pengumpulan data-data dari internal organisasi. Data-data yang biasanya digunakan adalah dokumen visi misi perusahaan, peraturan perusahaan atau perjanjian kerja bersama, prosedur operasi yang sudah distandarisasikan, dan dokumen lain yang dapat memberikan histori jabatan yang akan dianalisis. Selanjutnya, analis jabatan (sebutan untuk orang yang melakukan analisis jabatan dilakukan oleh manajemen SDM) akan mempelajari dokumen tersebut dan menggali informasi mengenai suatu jabatan.

Setelah mendapatkan informasi dari data yang sudah ada, analis jabatan akan terjun ke lapangan mengadakan penyebaran kuesioner; wawancara dengan pemangku jabatan/incumbent, atasan/superior, rekan/peer, dan bawahan/subordinate; serta observasi. Proses terjun di lapangan ini dilakukan untuk organisasi yang proses bisnisnya sudah berjalan. Artinya, sudah ada kegiatan yang dilakukan. Di lapangan ini, analis jabatan akan menggali mengenai tanggung jawab dan wewenang jabatan, tugas-tugas yang dijalankan, prosedur standar dalam operasionalisasi, kendala dan hambatan, dan pihak yang biasa terlibat dalam penanganan pekerjaan (stakeholders). Jadi, sebelum mengadakan wawancara, biasanya analis jabatan akan menyebarkan kuestioner yang berisi pertanyaan seputar hal tersebut.

Ketika pulang dari lapangan, analis jabatan akan menggenggam informasi yang akan diramu menjadi uraian jabatan dan persyaratan jabatan. Dia akan membuat draf atas informasi tersebut. Draf uraian jabatan dan persyaratan jabatan tersebut selanjutnya akan dikonsultasikan kembali dan menunggu persetujuan dengan atasan. Analisis jabatan yang dipakai oleh perusahaan adalah dengan menggunakan metode kuesioner dan wawancara karena metode kuesioner dapat mengumpulkan informasi dengan mudah dan dalam waktu yang relatif singkat. Setelah mendapatkan data kuesioner untuk menghindari persepsi yang berbeda dari isi kuesioner yang diberikan, maka harus ditinjau kelengkapannya, dengan tindakan lanjut yang seperlunya dalam bentuk wawancara dengan pertanyaan tambahan yang harus dijawab oleh para karyawan. Perusahaan melakukan analisis jabatan secara berkala. Analisis jabatan digunakan untuk mengubah visi, misi perusahaan dan mengubah struktur organisasi untuk penambahan divisi atau pengurangan divisi. 


\section{Pembahasan Perencanaan Sumber Daya Manusia}

Perencanaan SDM merupakan proses untuk menghitung dan merencanakan jumlah kebutuhan pegawai yang paling optimal bagi perusahaan. Kegiatan ini merupakan salah satu langkah awal untuk menciptakan jumlah karyawan yang paling pas dengan kebutuhan perusahaan. Artinya, tidak terlalu berlebih sehingga tidak efisien atau kekurangan jumlah pegawai sehingga lambat mengantisipasi perkembangan bisnis. Ada 3 faktor yang harus dipertimbangkan dalam melakukan perencanaan SDM. Faktor pertama adalah estimasi jumlah karyawan yang akan keluar (baik secara alami melalui proses pensiun) atau karena yang mengundurkan diri. Data karyawan yang akan pensiun bisa dilihat dari database karyawan, sementara tren karyawan yang resign bisa dilihat tren turn over pegawai dalam 3 tahun terakhir. Faktor kedua adalah rencana bisnis perusahaan di masa mendatang; apakah hendak melakukan ekspansi pasar dan membuka cabang bisnis baru atau justru sebaliknya, akan menghadapi penurunan penjualan sehingga operasi bisnis akan makin diciutkan. Rencana bisnis ini sangat penting bagi proses perencanaan kebutuhan jumlah SDM. Faktor yang ketiga yang juga harus dipertimbangkan dalam perencanaan SDM adalah sumber daya keuangan perusahaan; apakah perusahaan memiliki anggaran yang cukup memadai untuk mempertahankan jumlah karyawan atau juga melakukan penambahan. Atau sebaliknya, kondisi keuangan perusahaan kian sulit sehingga justru harus dilakukan PHK.

Metode perencanaan yang dilakukan oleh perusahaan adalah menggunakan metode analisis regresi statistis, dimana analisis regresi statistis dilakukan dengan cara perbandingan statistik berdasarkan hubungan berbagai faktor di masa lalu. Contohnya di perusahaan adalah sebagai berikut. Hubungan statistik antara penjualan kotor dan jumlah karyawan dalam rantai ritel akan berguna dalam meramalkan jumlah karyawan yang dibutuhkan jika penjualan tersebut meningkat sebanyak $30 \%$. Perencanaan SDM pada perusahaan dilakukan secara berkala, di mana perencanaan SDM harus disesuaikan dengan tujuan dan strategi perusahaan tersebut. Kesimpulan yang didapat dari hasil wawancara dengan perusahaan mengenai perencanaan SDM bahwa perusahaan telah melakukan perencanaan SDM dengan baik.

\section{Pembahasan Rekrutmen}

Kebijakan rekrutmen terkait tentang darimana SDM diperoleh. Pada dasarnya, rekrutmen dapat berasal dari 2 sumber yaitu, eksternal dan internal. Perusahaan akan memilih tenaga kerja dari dalam atau dari luar tergantung beberapa faktor, termasuk ketersediaan orang-orang yang berkualitas, kondisi perekonomian, rencana organisasi, biaya relatif, dan kebijakan SDM.

Perusahaan memakai metode perekrutan yang berfokus pada karyawan karena dengan alasan dapat menekan biaya perekrutan menjadi rendah dan bagi pekerja-pekerja baru yang direkrut melalui referensi karyawan mempunyai masa kerja dalam organisasi yang lebih lama. Selain itu, perusahaan juga melakukan promosi dan transfer pekerjaan untuk mengisi tempat-tempat yang strategis berasal dari dalam perusahaan. Promosi dan transfer pekerjaan dengan merekrut dari dalam perusahaan itu sendiri dipilih dengan alasan untuk menghemat biaya, menghemat waktu yang diperlukan untuk mengisi lowongan, dan karyawan yang akan dipromosikan tentunya mengenal dengan baik keadaan perusahaan itu sendiri dan sebelum karyawan yang akan hendak keluar dari perusahaan, maka karyawan yang akan keluar tersebut wajib memberikan pelatihan kepada calon pengganti yang akan mengisi posisi yang akan dia tinggalkan atau lebih dikenal dengan pelatihan on the job training. 


\section{SIMPULAN}

Berdasarkan hasil analisis dan pembahasan mengenai peranan analisis jabatan dan perencanaan SDM terhadap rekrutmen karyawan, maka dapat ditarik kesimpulan sebagai berikut. Analisis jabatan memiliki hubungan yang kuat dengan efektifitas rekrutmen karyawan, dapat diartikan bahwa hubungan antara variabel analisis jabatan dengan variabel rekrutmen karyawan sebesar 0,702 dan mempunyai pengaruh sebesar 49,3\%. Perencanaan SDM memiliki hubungan yang kuat terhadap efektivitas rekrutmen karyawan. Dapat diartikan bahwa hubungan antara variabel perencanaan SDM dengan variabel rekrutmen karyawan sebesar 0,736 dan mempunyai pengaruh sebesar 54,1\%. Dapat diartikan bahwa, perusahaan memiliki perencanaan SDM yang signifikan berpengaruh besar terhadap efektivitas rekrutmen karyawan. Perencanaan SDM memiliki hubungan yang kuat terhadap efektivitas rekrutmen karyawan. Dapat diartikan bahwa hubungan antara variabel perencanaan SDM dengan variabel rekrutmen karyawan sebesar 0,778 dan mempunyai pengaruh sebesar 60,5\%. Dapat diartikan bahwa perusahaan memiliki perencanaan SDM yang signifikan berpengaruh besar terhadap efektivitas rekrutmen karyawan.

Berdasarkan hasil analisis dan pembahasan, maka saran-saran yang dapat diberikan kepada perusahaan sehubungan dengan peranan analisis jabatan dan perencanaan SDM terhadap efektivitas rekrutmen karyawan pada perusahaan adalah sebagai berikut. Upaya-upaya yang dapat dilakukan adalah perlu melakukan observasi, di mana observasi tersebut dengan pengamatan dan memperhatikan individu yang melakukan pekerjaan guna mendeskripsikan tugas dan kewajiban yang dikerjakan. Jadi, dengan melakukan observasi dan bersama-sama dengan metode yang lain akan membuat analisis jabatan menjadi lebih baik lagi. Upaya-upaya untuk memperbaiki perencanaan SDM dilakukan dengan jalan mengevaluasi kembali sumber-sumber pasokan tenaga kerja di perusahaan, baik sumber pasokan tenaga kerja dari dalam perusahaan dan luar perusahaan serta mempertimbangkan kebutuhan pribadi perusahaan masih memerlukan ada atau tidaknya penambahan tenaga kerja. Secara bersama-sama analisis jabatan dan perencanaan SDM mempengaruhi efektivitas rekrutmen karyawan perusahaan. Namun, perusahaan disarankan agar lebih berfokus pada perencanaan SDM karena memiliki pengaruh yang kuat dan signifikan terhadap rekrutmen karyawan.

\section{DAFTAR PUSTAKA}

Ivancevich, J.M. (2007). Human resource management, Singapore: Mc Graw Hill.

Llyod, B., and Rue, L.E. (2006). Human resource management, $5^{\text {th }}$ ed., Prentice Hall.

Millmore, M., et al. (2007). Strategic human resource management, United Kingdom: Prentice Hall.

Millner and Crane. (2007). Human resource management, Prentice Hall.

Mondy, R,W. (2010). Human resource management, $11^{\text {th }}$ ed., New Jersey: Pearson Education.

Sugiyono. (2008). Metode penelitian bisnis, Bandung: Alfabeta.

Sukardi. (2003). Metodologi penelitian bisnis, Jakarta: PT Bumi Aksara.

Supranto, J. (2001). Pengukuran tingkat kepuasan kinerja, Jakarta: PT Rineka Cipta. 